\title{
Stature estimation from tibia percutaneous length: New equations derived from a Mediterranean population
}

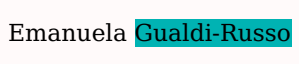

Barbara

brmbbr@unife.it

Natascia Rinaldo

rnlnsc@unife.it

Department of Biomedical Sciences and Surgical Specialties, University of Ferrara, Corso Ercole I D"_Este 32, 44121 Ferrara, Italy

*Corresponding authors

\section{ABSTRACTbstract}

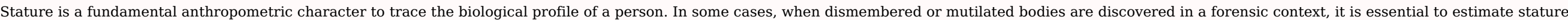

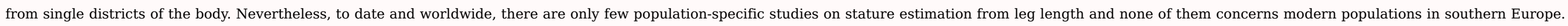

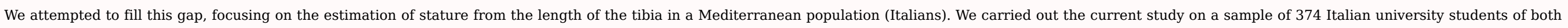

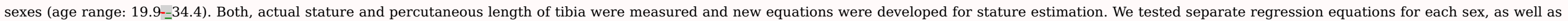

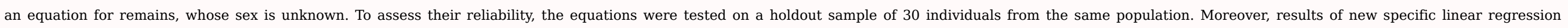

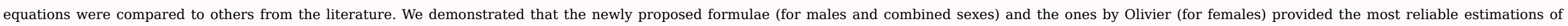
stature for southern Europeans.

Keywords: Stature estimation; Tibia length; Italy; Forensic Aạnthropology

\subsection{Introduction}

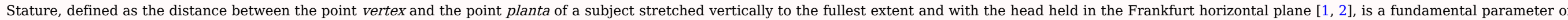

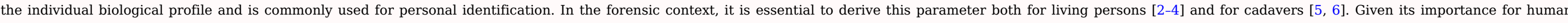

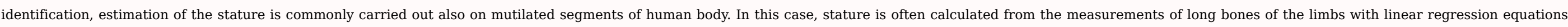

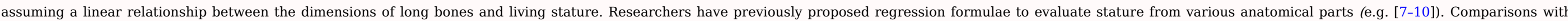

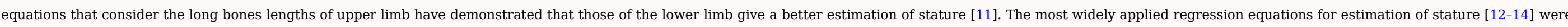

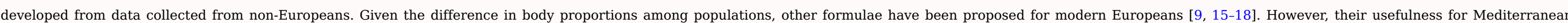

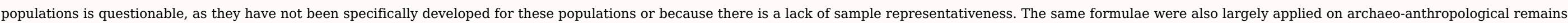

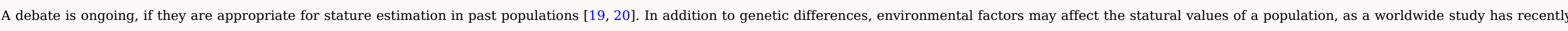
shown [21]. This evidence highlighted the need for specific formulae for each population or ethnic group.

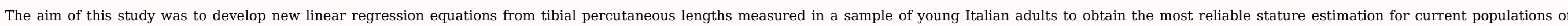
southern Europe.

\subsection{Materials and Mmethods}

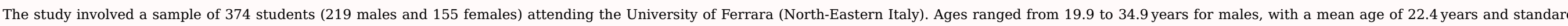




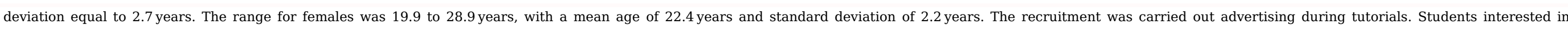

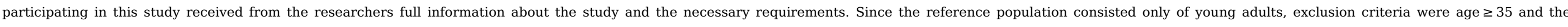

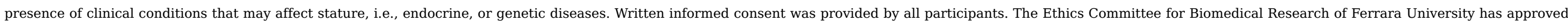
the experimental protocol.

\subsubsection{Measurements}

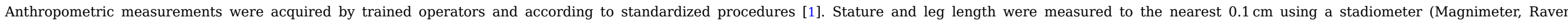

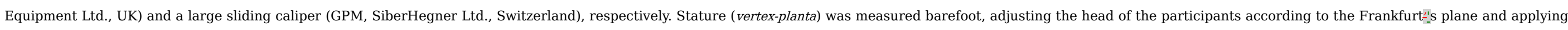

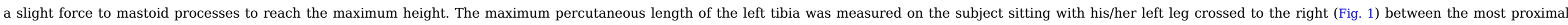
landmark of medial condylar margin and the most distal one of the medial malleolus margin [22 (Need to be subsituted with reference [23])].

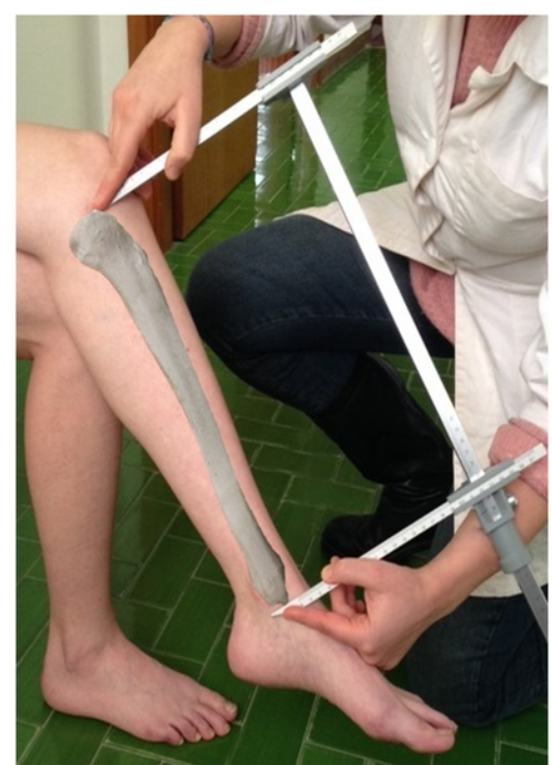

Fig. 1 Anthropometric measurement of percutaneous tibia length!

\section{alt-text: Fig. 1}

\subsubsection{Statistical analyses}

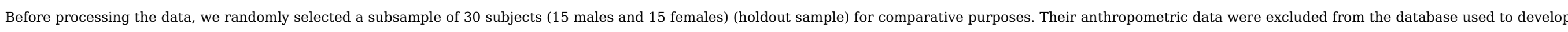

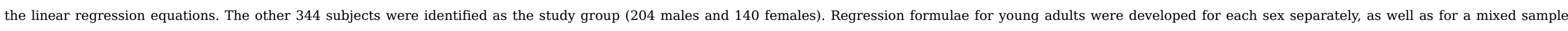

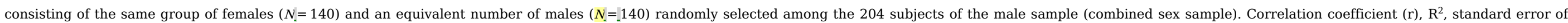
estimate (SEE) were computed.

The independent $t$-test was used to test the difference in stature and tibial length between the two sexes.

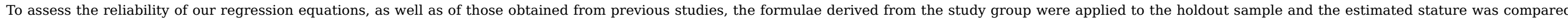

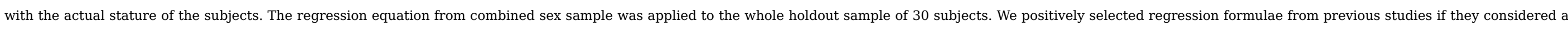

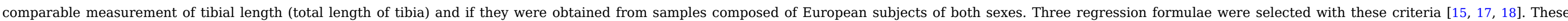




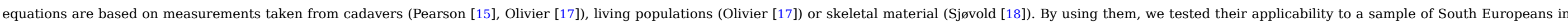
comparison to our equations.

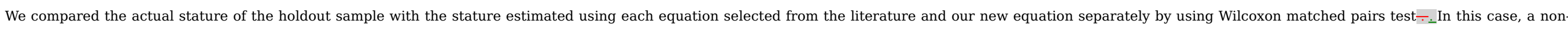

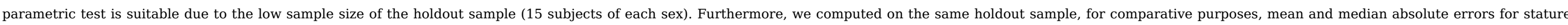
estimations and percent prediction error (PPE) as $=100 \times$ [(regression estimate - measured stature)/measured stature].

Statistical analysis was performed using Statistica for Windows (version 11.0, StatSoft srl, Tulsa, OK).

\section{3. $\underline{3}$ Results}

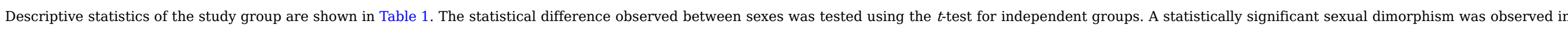
both anthropometric measurements with an average difference between males and females of $13.3 \mathrm{~cm}$ in stature and $3.1 \mathrm{~cm}$ in tibia length.

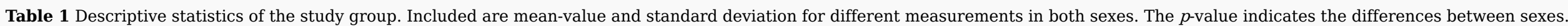
alt-text: Table 1

\begin{tabular}{|c|c|c|c|c|c|}
\hline \multirow{2}{*}{ Variables $^{\mathrm{a}}$} & \multicolumn{2}{|c|}{ Males $(n=219)$} & \multicolumn{2}{|c|}{ Females $(n=155)$} & \multirow{2}{*}{$p$ value } \\
\hline & Mean & SD & Mean & SD & \\
\hline Stature, $\mathrm{cm}$ & 178.2 & 7.0 & 164.9 & 6.8 & $<0.001^{\mathrm{a}}$ \\
\hline Tibial length, cm & 40.2 & 2.9 & 37.1 & 2.7 & $<0.001^{\mathrm{a}}$ \\
\hline
\end{tabular}

a Statistical analysis performed using $\underline{t} \underline{t}$-test.

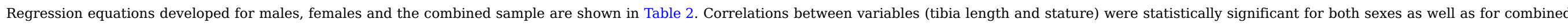

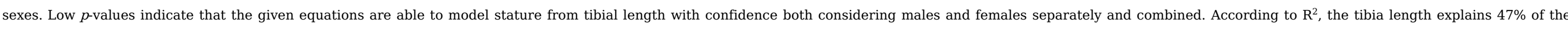

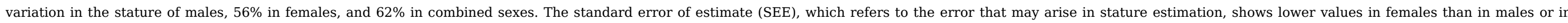

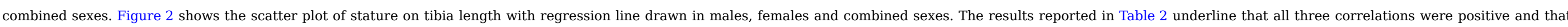

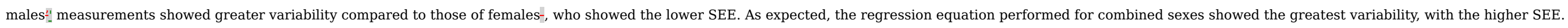

Table 2 Correlation coefficient and regression equations for the estimation of stature in males, females and combined sexes.

SEE: standard error of estimate; Y: stature (cm); X: tibia length (cm). 

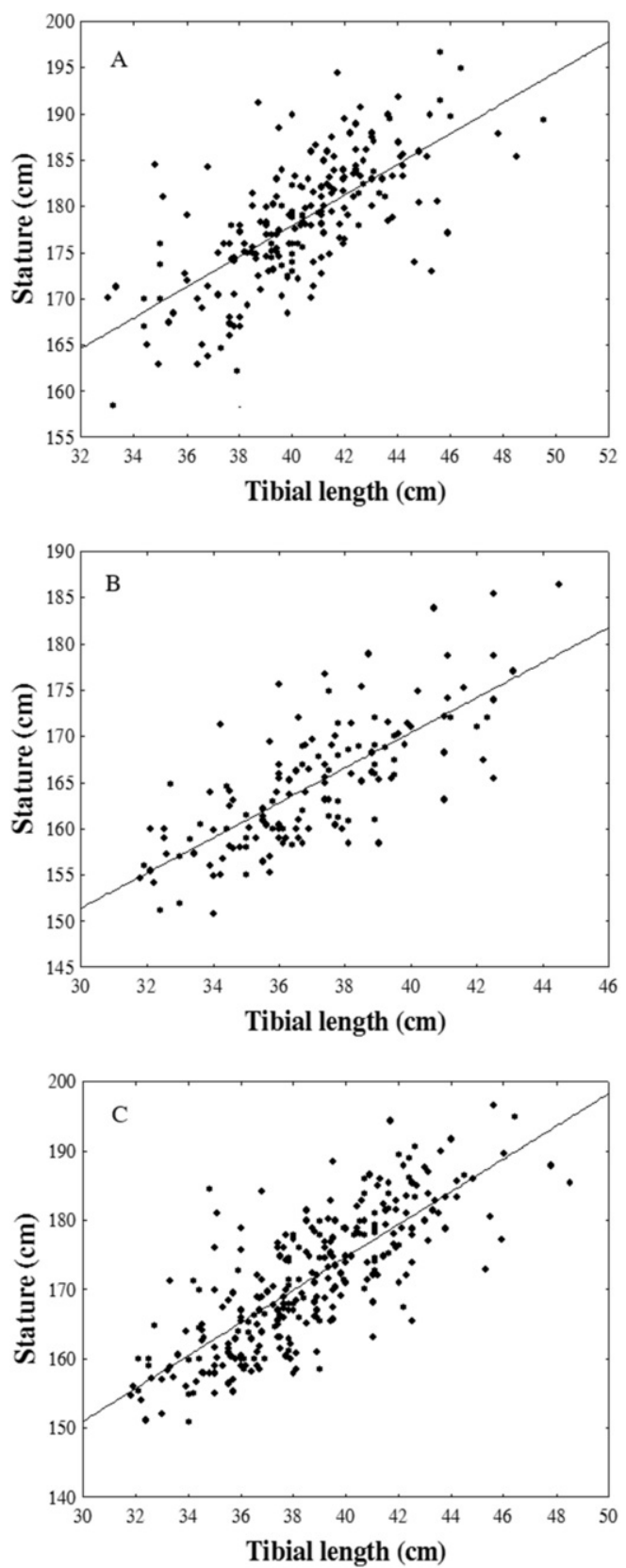

Fig. 2 Scatter plots illustrating the association between living stature and tibia length in males (A), females (B) and combined sample (C), alt-text: Fig. 2

The comparison, performed on the holdout sample from the same population between stature estimated with the developed equations and its actual value, did not show any statistical difference (Table 3). 
Table 3 Descriptive statistics (medians and range) of the actual stature of the holdout sample and of the estimated stature after the application of the regression equations. alt-text: Table 3

\begin{tabular}{|c|c|c|c|c|c|c|c|c|c|c|}
\hline \multirow[t]{4}{*}{ Sex } & \multirow[t]{4}{*}{$n$} & Actual stature & Current study & \multirow[t]{2}{*}{1 vs 2} & Pearson [15] & \multirow[t]{2}{*}{1 vs 3} & Olivier [17] & \multirow[t]{2}{*}{1 vs 4} & Sjøvold [18] & \multirow[t]{2}{*}{1 vs 5} \\
\hline & & 1 & 2 & & 3 & & 4 & & 5 & \\
\hline & & Median & Median & \multirow[t]{2}{*}{$p$} & Median & \multirow[t]{2}{*}{$p$} & Median & \multirow[t]{2}{*}{$p$} & Median & \multirow[t]{2}{*}{$p$} \\
\hline & & (range) & (Range) & & (Range) & & (Range) & & (Range) & \\
\hline \multirow[t]{2}{*}{ Males } & \multirow[t]{2}{*}{15} & 174.6 & 175.0 & \multirow[t]{2}{*}{0.721} & 169.6 & \multirow[t]{2}{*}{0.004} & 171.1 & \multirow[t]{2}{*}{0.114} & 174.3 & \multirow[t]{2}{*}{0.386} \\
\hline & & $(163.8-=180.0)$ & (163.6--178.6) & & (153.4--175.8) & & (153.4--177.8) & & $\left(153.8^{--}=182.1\right)$ & \\
\hline \multirow[t]{2}{*}{ Females } & \multirow[t]{2}{*}{15} & 168.6 & 167.8 & \multirow[t]{2}{*}{0.114} & 165.6 & \multirow[t]{2}{*}{0.005} & 169.3 & \multirow[t]{2}{*}{0.752} & 165.7 & \multirow[t]{2}{*}{0.005} \\
\hline & & $(161.0=178.5)$ & (159.6-=174.4) & & (155.4-_173.7) & & (159.3-=177.2) & & $-(162.5-=186.1)$ & \\
\hline \multirow[t]{2}{*}{ Unknown } & \multirow[t]{2}{*}{30} & 169.9 & 171.5 & \multirow[t]{2}{*}{0.390} & \multirow[t]{2}{*}{$=$} & \multirow[t]{2}{*}{$=$} & $=$ & \multirow[t]{2}{*}{$=$} & 175.7 & \multirow[t]{2}{*}{0.263} \\
\hline & & $(161.0=180.0)$ & (154.3-=179.6) & & & & & & $(153.8-=186.1)$ & \\
\hline
\end{tabular}

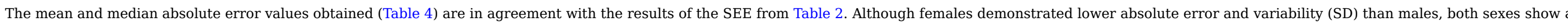

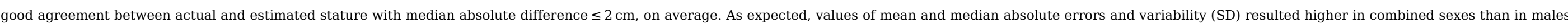

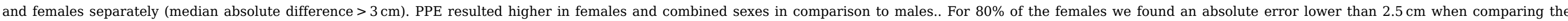

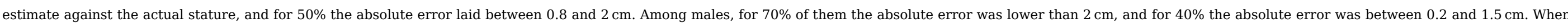
testing the equation for combined sexes, the absolute error was lower than $2 \mathrm{~cm}$ only in the $45 \%$ of cases.

Table 4 Absolute error after application of regression equations to a holdout sample.

\begin{tabular}{|c|c|}
\hline alt-text: Table \\
Sex $n$
\end{tabular}

Current study

Pearson [15]

Mean abs error Median abs error Mean PPE Mean abs error

Females $15 \mid 1.99$

\begin{tabular}{l|l|l} 
Unknown & 30 & 3.64
\end{tabular}

\begin{tabular}{l|l|}
0.080 & 5.88 \\
\hline$-=0.704$ & 3.65 \\
\hline-0.798 & - \\
\hline
\end{tabular}

3.23

$-=0.798$
6.69

4.63

$-$

Males $\quad 15 \quad 2.54$

Olivier [17]

Sjøvold [18] - Caucasians

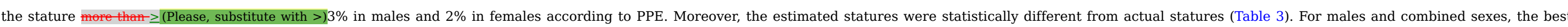

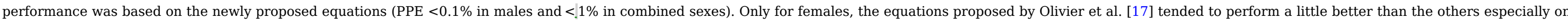

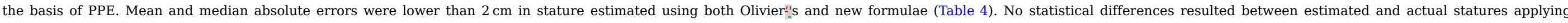
Sjøvold IIIs formulas [18], except for female stature (overestimated than $\geq$ (Please, substitute with $>$ ) $3 \%$ ) (Table 3).

\subsection{Discussion}

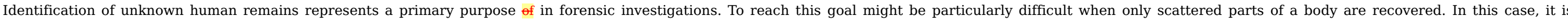

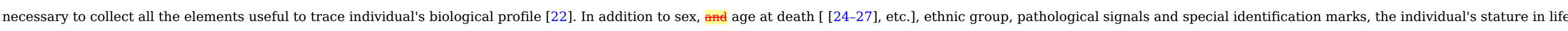

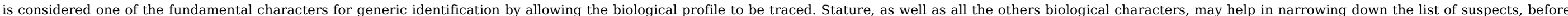




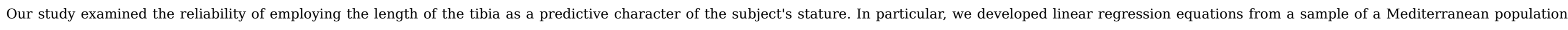

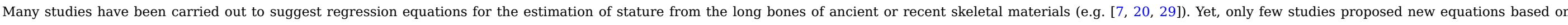

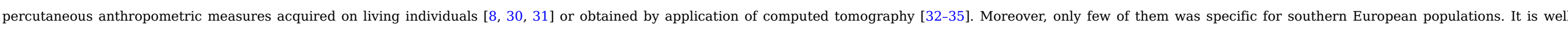

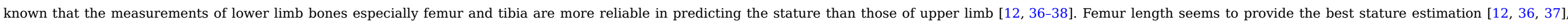

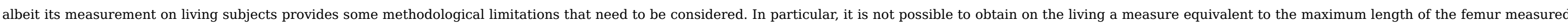

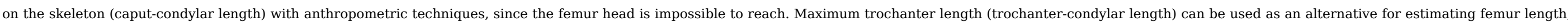

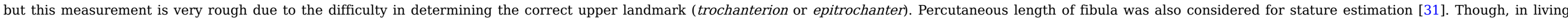
people, leg length measured between the landmarks of the tibia is, in any case, more easily to determine.

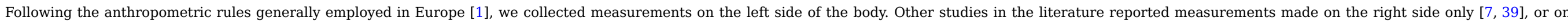
both sides [31, 32]. In the last case, no statistical difference was observed for stature estimation obtained from the left or the right long bones [31, 32].

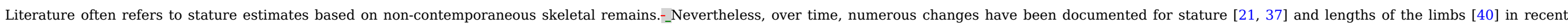
human populations. Therefore, if equations need to be applicable in a forensic context, the data on which they were developed on should preferably be from contemporaneous populations.

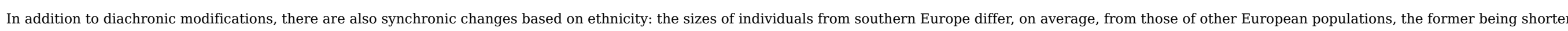

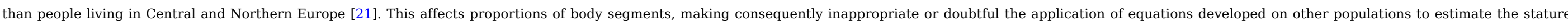
among southern European subjects.

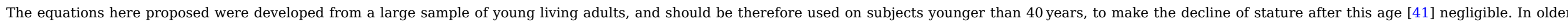

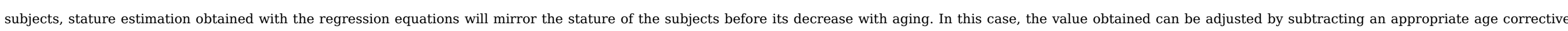

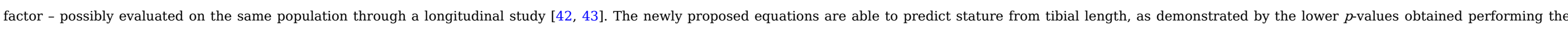

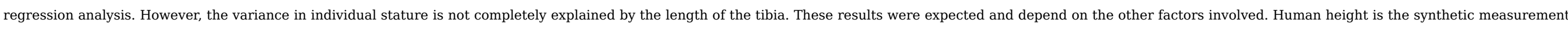

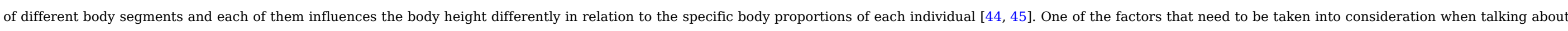

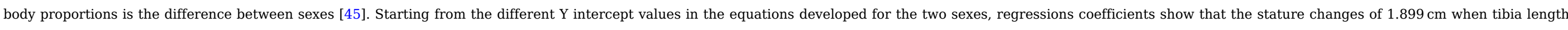

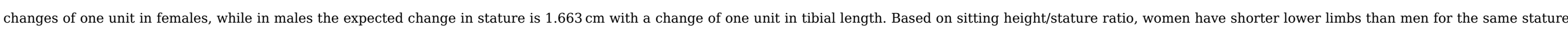
[46]. Furthermore, women have shorter legs than men, unlike the thigh which tends to be longer [47]. Similar results are reported by Sah et al. [10].

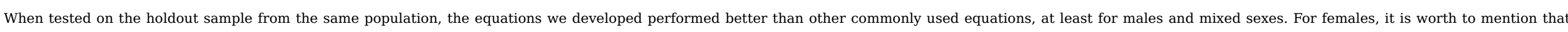

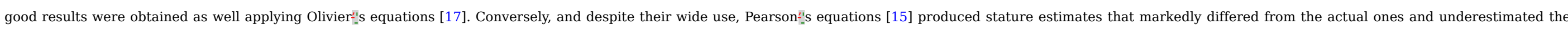

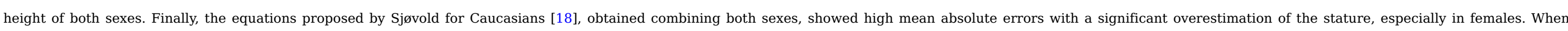

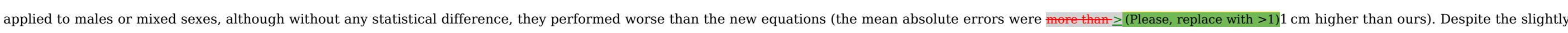

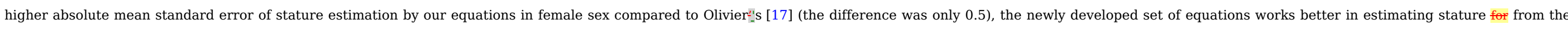
tibia than those taken from literature.

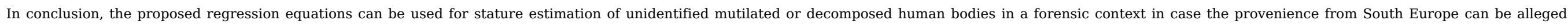
Future research should investigate the applicability of these equations to other samples of European populations.

\section{Uncited reference}




\section{Acknowledgements}

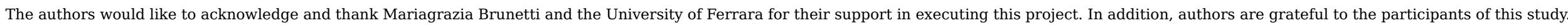

\section{Funding}

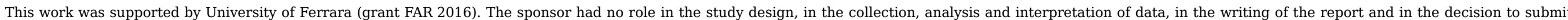

the article for publication.

\section{Declarations of interest}

None.

\section{References}

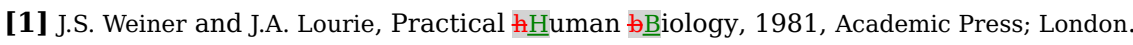

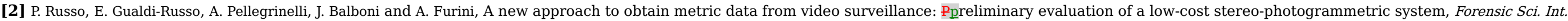
271, 2017, 59-67, https://doi.org/10.1016/j.forsciint.2016.12.023.

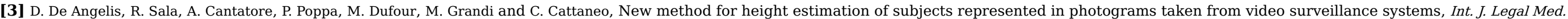
121, 2007, 489-492, https://doi.org/10.1007/s00414-007-0176-4.

[4] B. Hoogeboom, I. Alberink and M. Goos, Body height measurements in images, J. Forensic Sci. 54, 2009, 1365-1375, https://doi.org/10.1111/j.1556-4029.2009.01179.x.

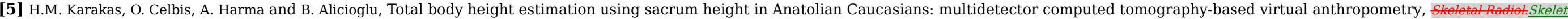
Radiol. 40, 2011, 623-630, https://doi.org/10.1007/s00256-010-0937-x.

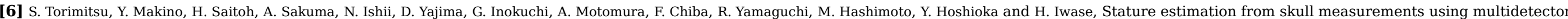
computed tomographic images: A Japanese forensic sample, Leg. Med. (Tokyo) 18, 2016, 75-80, https://doi.org/10.1016/j.legalmed.2015.12.010.

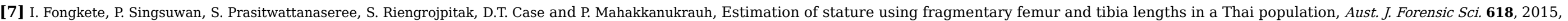
1-10, https://doi.org/10.1080/00450618.2015.1052758.

[8] A. Özaslan, M.Y. Işcan, I. Özaslan, H. Tuğcu and S. Koç, Estimation of stature from body parts, Forensic Sci. Int. 132, 2003, 40-45, https://doi.org/10.1016/S0379-0738(02)00425-5.

[9] D. Radoinova, K. Tenekedjiev and Y. Yordanov, Stature estimation from long bone lengths in Bulgarians, Home-Homo 52, 2002, 221-232, https://doi.org/10.1078/0018-442X-00030.

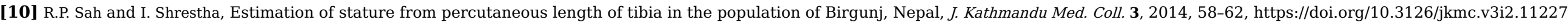

[11] G. Fully, Une nouvelle méthode de détermination de la taille, Ann. Med. Leg. 35, 1956, 266-273.

[12] M. Trotter and G.C. Gleser, Estimation of stature from long bones of American Whites and Negroes, Am. J. Phys. Anthropol. 10, 1952, 463-514, https://doi.org/10.1002/ajpa.1330100407.

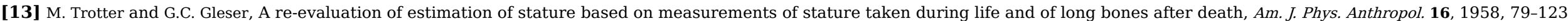
https://doi.org/10.1002/ajpa.1330160106.

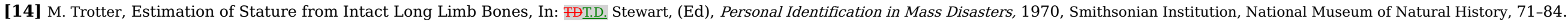

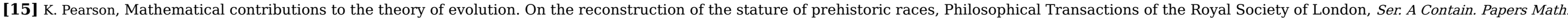
Phys. Character 192, 1899, 169-244. 
[16] A. Telkkä, On the prediction of human stature from the long bones, Eells Tisstes Organs:Cells Tissues Organs 9, 1950, $103-117$.

[17] G. Olivier, C. Aaron, G. Fully and G. Tissier, New estimations of stature and cranial capacity in modern man, J. Hum. Evol. 7, 1978, 513-518, https://doi.org/10.1016/S0047-2484(78)80020-7.

[18] T. Sjøvold, Estimation of stature from long bones utilizing the line of organic correlation, Hum. Evol. 5, 1990, 431-447, https://doi.org/10.1007/BF02435593.

[19] V. Formicola, More is not always better: Ftrotter and Gleser!-s equations and stature estimates of Uupper Paleolithic European samples, J. Hum. Evol. 45, 2003, 239-244.

[20] M. Giannecchini and J. Moggi-Cecchi, Stature in archeological samples from $\in$ Central Italy: Mmethodological issues and diachronic changes, Am. J. Phys. Anthropol. 135, 2008, 284-292, https://doi.org/10.1002/ajpa.20742.

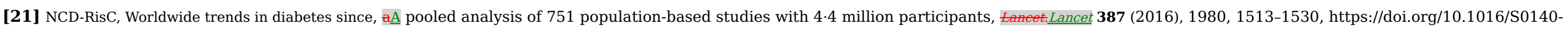
6736(16)00618-8.

[22] C. Cattaneo and M. D'Amico, I diritti annegati: I morti senza nome del Mediterraneo, 2016, Franco Angeli; Milano.

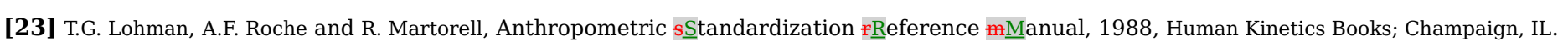

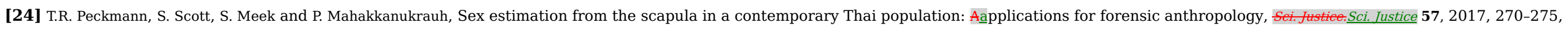
https://doi.org/10.1016/j.scijus.2017.02.005.

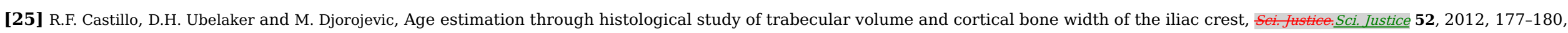
https://doi.org/10.1016/j.scijus.2011.09.004.

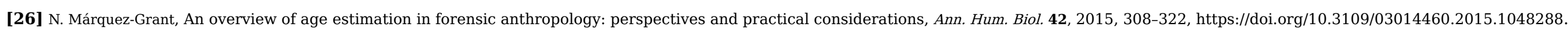

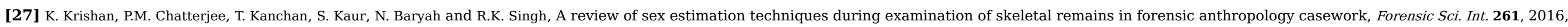
e1-ę8, https://doi.org/10.1016/j.forsciint.2016.02.007.

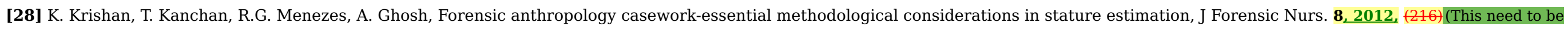
deleted. The correct year of publication is 2012)-45-=50.

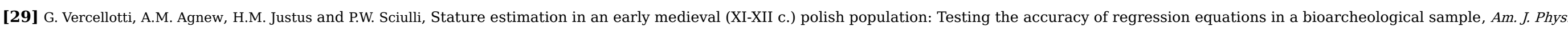
Anthropol. 140, 2009, 135-142, https://doi.org/10.1002/ajpa.21055.

[30] I. Duyar and C. Pelin, Body height estimation based on tibia length in different stature groups, Am. J. Phys. Anthropol. 122, 2003, 23-27, https://doi.org/10.1002/ajpa.10257.

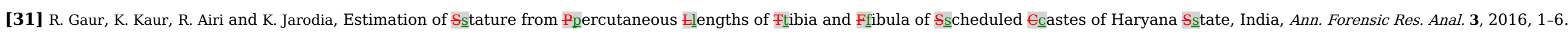

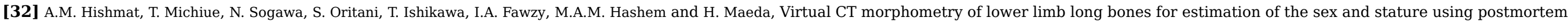
Japanese adult data in forensic identification, Int. J. Legal Med. 129, 2015, 1173-1182, https://doi.org/10.1007/s00414-015-1228-9.

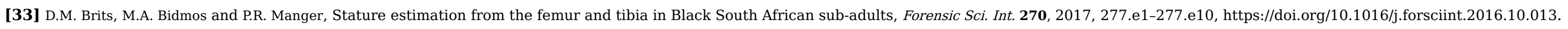

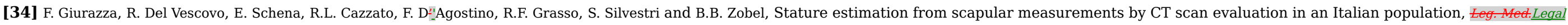
Med. 15, 2013, 202-208, https://doi.org/10.1016/j.legalmed.2013.01.002.

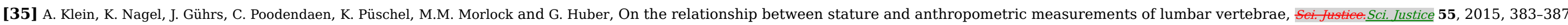
https://doi.org/10.1016/j.scijus.2015.05.004. 


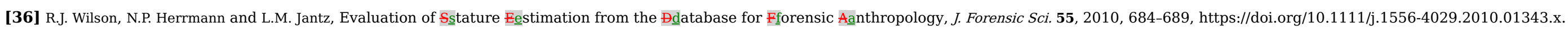

[37] P. Mahakkanukrauh, P. Khanpetch, S. Prasitwattanseree, K. Vichairat and D. Troy Case, Stature estimation from long bone lengths in a Thai population, Forensic Sci. Int. 210, 2011, https://doi.org/10.1016/j.forsciint.2011.04.025.

[38] M.R. Dayal, M. Steyn and K.L. Kuykendall, Stature estimation from bones of South African whites, S. Afr. J. Sci. 104, 2008, $124-128$.

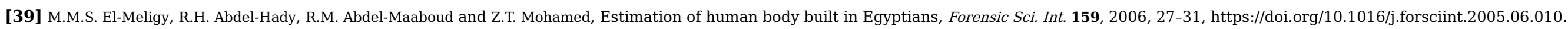

[40] L.M. Jantz and R.L. Jantz, Secular change in long bone length and proportion in the United States, 1800-1970, Am. J. Phys. Anthropol. 110, 1999 , 57-67.

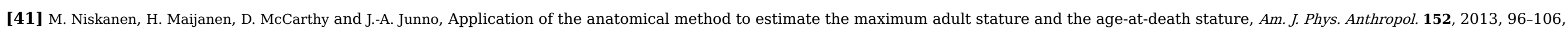
https://doi.org/10.1002/ajpa.22332.

[42] E. Giles, Corrections for age in estimating older adults!'- stature from long bones, J. Forensic Sci. 36, 1991, 898-901.

[43] P.J. Chandler and R.D. Bock, Age changes in adult stature: trend estimation from mixed longitudinal data, Ann. Hum. Biol. 18, 1991, 433-440.

[44] K. Silventoinen, Determinants of variation in adult body height, foumal of $263-285$.

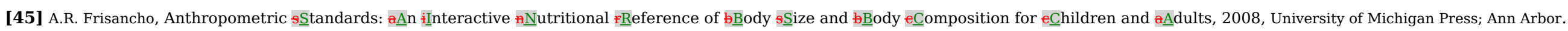

[46] R.M. Malina, C. Bouchard and O. Bar-Or, Growth, Maturation, and Physical Activity, 2nd ed., 2004, Human Kinetics; Champaign, 41-81.

[47] F. Facchini, Antropologia, 1995, Evoluzione; Uomo, Ambiente, UTET, Torino, 253-268.

\section{Highlights}

- Tibia percutaneous length is highly correlated with stature.

- New regression equations for stature estimation from tibial length have been developed.

- The new formulae provide a reliable estimation of stature for southern Europeans.

\section{Queries and Answers}

Query:

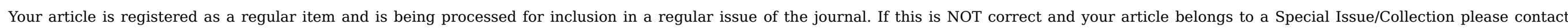
PA.Crabtr@elsevier.com immediately prior to returning your corrections.

Answer: I confirm that this article is a regular item and has to be included in a regular issue

Query:

Please confirm that given names and surnames have been identified correctly and are presented in the desired order, and please carefully verify the spelling of all authors' names. 
Query:

The author names have been tagged as given names and surnames (surnames are highlighted in teal color). Please confirm if they have been identified correctly.

Answer: Yes

Query:

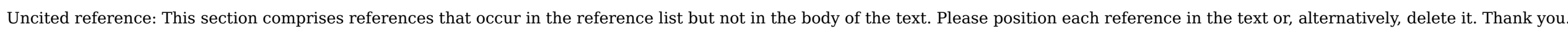

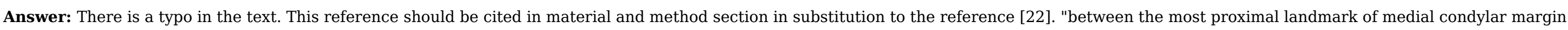
and the most distal one of the medial malleolus margin [23]."

Query:

Please supply the year of publication.

Answer: The correct year of publication is 2012 doi: 10.1111/j.1939-3938.2011.01122.x. 